PALEO

Revue d'archéologie préhistorique

$23 \mid 2012$

Varia

\title{
Did Gravettian apprentices make projectile elements in Tercis (Landes, France)?
}

Aurélien Simonet

\section{(2) OpenEdition}

1 Journals

Electronic version

URL: http://journals.openedition.org/paleo/2463

DOI: $10.4000 /$ paleo.2463

ISSN: 2101-0420

Publisher

SAMRA

Printed version

Date of publication: 15 December 2012

Number of pages: 249-276

ISSN: 1145-3370

\section{Electronic reference}

Aurélien Simonet, « Did Gravettian apprentices make projectile elements in Tercis (Landes, France)? », PALEO [Online], 23 | 2012, Online since 14 May 2013, connection on 26 July 2020. URL : http:// journals.openedition.org/paleo/2463; DOI : https://doi.org/10.4000/paleo.2463

This text was automatically generated on 26 July 2020 .

\section{(c) $(7)$}

PALEO est mis à disposition selon les termes de la licence Creative Commons Attribution - Pas d'Utilisation Commerciale - Pas de Modification 4.0 International. 


\title{
Did Gravettian apprentices make projectile elements in Tercis (Landes, France)?
}

\author{
Aurélien Simonet
}

\section{1 - Site presentation}

\section{1 - Geographic presentation}

1 The archaeological site of Tercis (Landes, France) is located southwest of Dax, on the south side of an anticline, on a hill about $60 \mathrm{~m}$ above the Adour River (fig. 1). It is made up of a complex of small flint concentrations collected as surface finds since the $19^{\text {th }}$ century. All of these concentrations spread from west to east at the top of a ridge over a distance of about a kilometer. It is probable that other occupations will be discovered in sectors which have not yet been exploited. The geological context presents many flint outcrops. The site is a huge knapping workshop used as a flint reserve by many Middle and Upper Palaeolithic human groups before contemporary limestone exploitation began for making lime (Normand 1987, 1993 ; Kozlowski \& Lenoir 1988 ; Kawalek 2008; Simonet 2004, 2009). The Gravettians appear to be particularly well represented among the paleolithic groups. Petroarchaeological studies of the Gravettian caves of Isturitz and Brassempouy, both located at an equal distance from Tercis (about thirty kilometers), confirm the significant use of Tercis flint, mainly for making backed points (Simonet 2009, 2010, 2012). At present, Tercis is the largest known workshop linked to the major sites of Isturitz and Brassempouy. Further north, Montaut, where Gravettian remains have also been identified, may represent an example of a flint knapping satellite site, using flint from the Audigon anticline (Merlet 1996). To the south, the recent discovery of the Avenue du Prissé site in Bayonne represents a new Gravettian marker where flint knapping activities play a preponderant role (Redondo 2011). 


\section{2 - Historiographic presentation}

2 The significance of the Tercis site attracted the attention of local erudites a long time ago, as far back as the end of the 19th century (Daguin 1948; Du Boucher 1877, 1878, 1879; Pottier 1872). It is paradoxical that the site was then neglected for most of the $20^{\text {th }}$ century. The works of R. Arambourou (1963) and especially the thesis of C. Thibault on Quaternary landforms in the Adour Basin (Thibault 1970) are thus the only university studies mentioning the Tercis site. C. Thibault provides accurate stratigraphic and sedimentological information, in particular, on the Vignès talus section. He mentions the abundance of laminar cores, burins and non-retouched blades and presents some pieces from the Emile Daguin collection, reassembled between 1911 and 1920, which he attributes to the evolved Perigordian. More recently, these same backed points from the Emile Daguin collection were studied using morphological and morphometric criteria (Kozlowski \& Lenoir 1988). Recent data embody the work of C. Normand who collected several series ascribed to the Aurignacian and the Gravettian and published the series of backed pieces (Normand 1987, 1993 ; Kawalek 2008 ; Simonet 2009).

Figure 1 - Location of the Tercis site in relation to Brassempouy, Isturitz and Gargas caves, the main Gravettian Pyrenees sites.

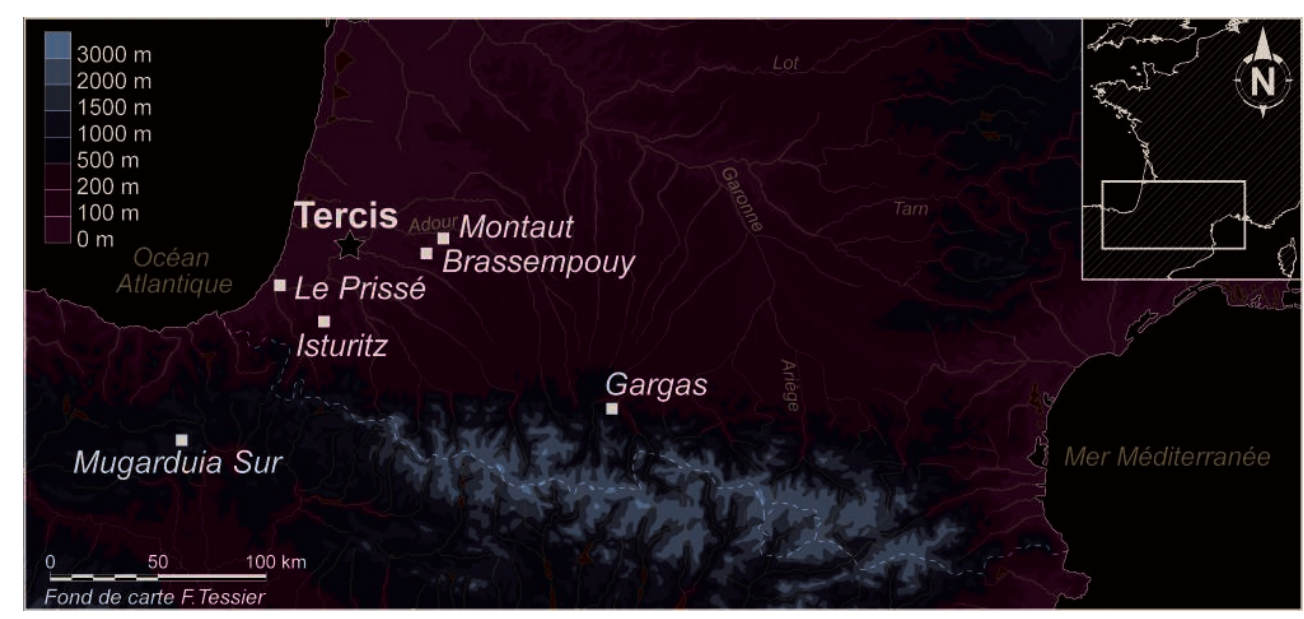

\section{3 - Presentation of the three main Gravettian series}

Most of the archaeological pieces correspond to surface finds separated from any stratigraphic and/or archaeological context and are consequently difficult to exploit. Three Gravettian series, each corresponding to the non-exhaustive collecting of a concentration, are particularly interesting in spite of the fact that some data are missing. One of these series was discovered by Emile Daguin near the Vignaux farm and is characterized by the presence of about thirty laminar cores and twenty projectiles (fig. 2). In addition, there are two concentrations partially collected by C. Normand in the early 1980s (fig. 2). One of these series displays quality laminar debitage and was referred to as the "series with big blades". The other contains backed pieces and was thus called the "series of backed pieces". At present, the Daguin series, which is currently conserved in the Aquitaine Museum in Bordeaux, and the large blade series are still largely unpublished. The backed pieces have already been partly published (Normand 1993 ; Simonet 2008). 


\section{4 - Presentation of the series of backed pieces}

4 This series was discovered about 500 meters west of the series gathered by Emile Daguin (fig. 2). It was urgently collected by C. Normand near « Les Vignès » in July 1982. C. Normand conducted a rescue excavation for four days during the short time period allotted by la Société des Ciments de l'Adour, who was working in the quarry at the time. Approximately 750 pieces were collected over a surface of two square meters but the initial dimensions of the concentration are unknown. It is thus a partial and peripheral gathering of a lithic concentration. The central part of the concentration was removed by machines (Normand, pers. com.). The study of this lithic series was the main subject of our degree dissertation (Simonet 2004).

\section{5 - Palaeo-sociological implications}

5 This series is original in that it presents a poorly executed debitage associated with about thirty unfinished or failed small backed pieces. This series occurs in a workshop knapping context which is paradoxically propitious to waste. As a direct consequence of this, it is difficult to refine the Gravettian attribution advanced by C. Normand, who retrieved the pieces (Normand 1993). This article aims to elucidate the palaeosociological implications of this assemblage which we hope will result from the accurate presentation of the data. Indeed, this series may represent one of the earliest signs of projectile making apprenticeship in the middle of the Upper Palaeolithic. This research perspective is all the more stimulating in that this subject has been very poorly documented up until now and no objective criteria for identifying apprenticeship have, as of yet, been identified (Pigeot 1988 ; Ploux 1991 ; Pelegrin 1995 ; Klaric 2006, in preparation). Founding work in the domain of lithic technology points towards a cluster of indispensable signs, like at the site of Étiolles for example (Pigeot 1986, 1988, 1990 ; Pigeot dir. 2004 ; Ploux 1989, 1991 ; Karlin et al. 1993 ; Pelegrin 1995 ; Bodu 1994). Nonetheless, the different levels of know-how and competence identified so far concern laminar debitage. There is no existing published documentation relating to the apprenticeship of projectile making during the Upper Palaeolithic and Tercis thus provides us with an innovative field of study which warrants future development.

\section{6 - Stratigraphic data}

Stratigraphic descriptions of the superficial formations covering the limestone strata of the Tercis anticline refer to a wider scale of several hundred square meters. It is thus possible that there are local variations within this broad geological context.

7 A layer of eolian sand corresponding to isotopic stage 2 was reported in this region (Thibault 1970 and fig. 3). At the base of this eolian sand layer it is possible to discern level $2 \mathrm{~b}$, which contains a mixture of several occupations (fig. 3), (Texier 1993). "Out of more than three hundred objects, there are about forty tools, including three Noailles burins, but also keeled end scrapers, Vachons burins and sidescrapers. Thus, it appears as though at least three industries are represented: Mousterian sensu lato, Aurignacian and Perigordian with Noailles burins" (Normand 1993 - p. 31). 
The series presented here was discovered in this eolian sand deposit, at the base of level $2 a$ which overlies level $2 b$ (fig. 3). At the scale of the Tercis site, level $2 b$ presents an association of heterogeneous pieces. However the typological and taphonomic data from level 2a seem to delimit a homogenous concentration. Indeed, the flint found in the underlying level is slightly patinated whereas flint from level 2a, attributed to the Gravettian, has a very fresh aspect.

On the other hand, a Solutrean industry lies under $20 \mathrm{~cm}$ of sand at Saussaye, just several hundred meters from the place where the Gravettian series were discovered. Yet, the Solutrean occupation is considered to be posterior to the deposition of the underlying eolian sands (Thibault 1970). These sands have thus been reworked in places and consequently, they do not define a terminus ante quem. Nonetheless, C. Thibault advances the following schema: the Solutrean is situated at the top of the sands whereas the Aurigacian is situated at the base. Thus, by correlation we can deduce that level 2 is probably Gravettian.

Figure 2 - Location of the main Gravettian concentrations from Tercis in relation to the quarry and the Mesozoic geological outcrops linked to the anticline. A to E: mining stages of the quarry. $\mathrm{N}^{\circ} 1$ : assemblage with large blades. $\mathrm{N}^{\circ} 2$ : assemblage with backed pieces. $\mathrm{N}^{\circ} 3$ : Daguin assemblage. Drawing and Photograph A. Simonet.

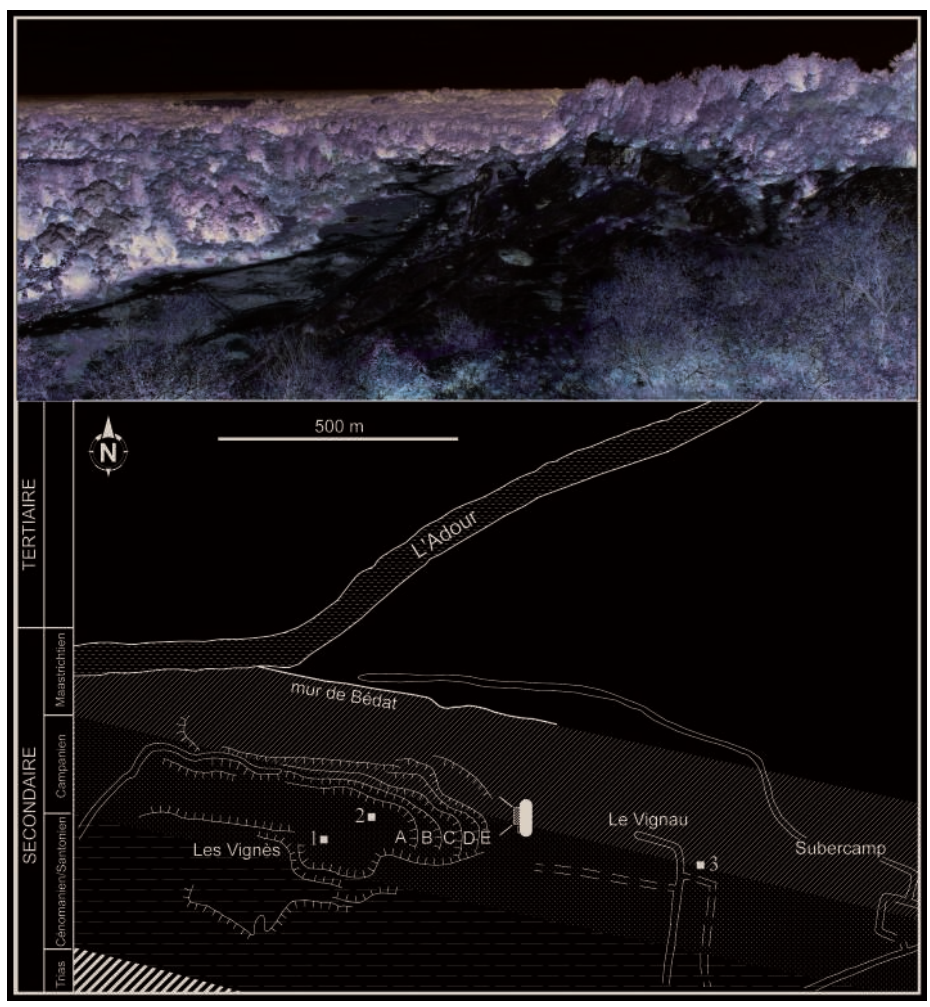


Figure 3 - Stratigraphy of the upper layers in Les Vignès. After Texier, 1993, fig. 2.

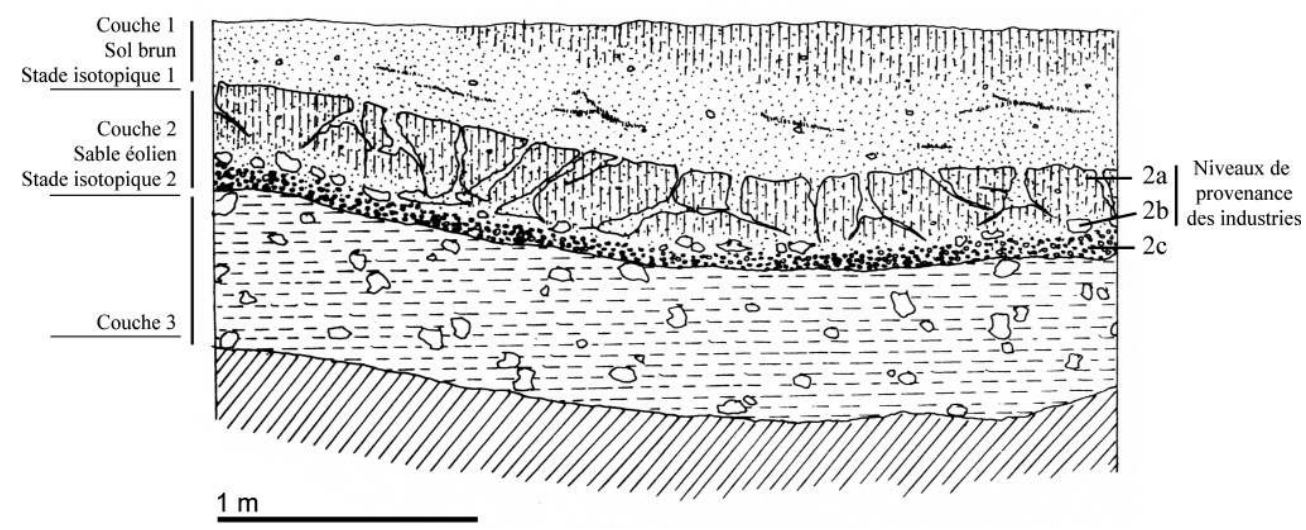

\section{2 - Presentation of the series of backed pieces}

\section{1 - Presentation of the corpus}

10 The assemblage is dominated by debitage products indicating the quest for small laminar products. Backed pieces predominate among the tools. Domestic tools are only marginally represented with four notched pieces and three retouched laminar products. Debitage products are mainly made up of flakes and shards with 512 pieces. The latter are completed by 171 laminar blade products, seven cores and five hard hammers on local quartzite pebbles (tab.1).

\section{2 - Raw materials}

11 The flint used is almost exclusively from the Upper Senonian limestone formations from the Tercis quarry (tab.1). This quarry contains high quality flint in a localized sector, known as "Tercis flint", which comes in three varieties. It is the first variety (a), a grey-black Maastrichtian flint, which was generally used during prehistoric times (fig. 2). Most of the elements from the series of backed pieces are in this raw material. It is a grey to black, translucent, fine-grained flint with rare recrystallizations and characteristic orangey-red spots. This flint has quite a variable aspect - it can be grey/ brown or black. It is a very good quality flint even though it appears to be a little dry. It acquires a grey-bluish patina which can be deep white. The nodules are rarely more than 25 centimeters long (Normand 2002).

12 The third variety of Tercis flint (c) is also present in this series (tab.1). It is a streaked white grey flint which had never been found before in the geological levels of Tercis quarry, although it is present in surface finds within a two to three kilometer radius (C. Normand, pers.com.). This type of flint was not often exploited. It was sometimes exported to sites like Brassempouy and Isturitz, but only very rarely. It is characterized by a thin cortex, a high quality zone directly under the cortex and a progressive decrease of this homogeneity towards the grainy center. This flint contains thin better silicified layers which give it a streaked aspect (Normand 2002). The Gravettian series with large blades is knapped in this variety of flint. Some of the blades are over 20 centimeters long, which is exceptional in the Chalosse regional context. In the series of 
backed pieces, only one core and two associated flakes are in this Tercis type flint. As the outcrop has not yet been discovered this flint type has not been precisely defined. Several characteristic Senonian sea urchins have nonetheless been identified (C. Normand, pers.com.).

13 A white-grey, good quality flint was used for one core and one blade product. This may be a sub variety of the Maastrichtian grey-black Tercis type flint (c. Normand, pers.com.). This raw material stands out amidst the majority of grey-black, medium quality Maastrichtian flint (tab.1).

Lastly, two flakes were made in Flysch flint from Bidache limestone (tabl. 1). This flint presents a potentially vast outcrop zone in the low Adour Valley. The nearest outcrops to Tercis are located twenty kilometers to the south. This is the most widely used siliceous raw material by the Gravettian occupants of Isturitz cave (Simonet 2010). This flint type occurs frequently as plates less than ten centimeters thick. It is a relatively fine grained flint, often opaque, grey, with frequent interstratifications parallel to the axis of the plate dotted by a multitude of micro-pits (Normand 2002).

Table 1 - Count of the backed pieces series and raw material distribution.

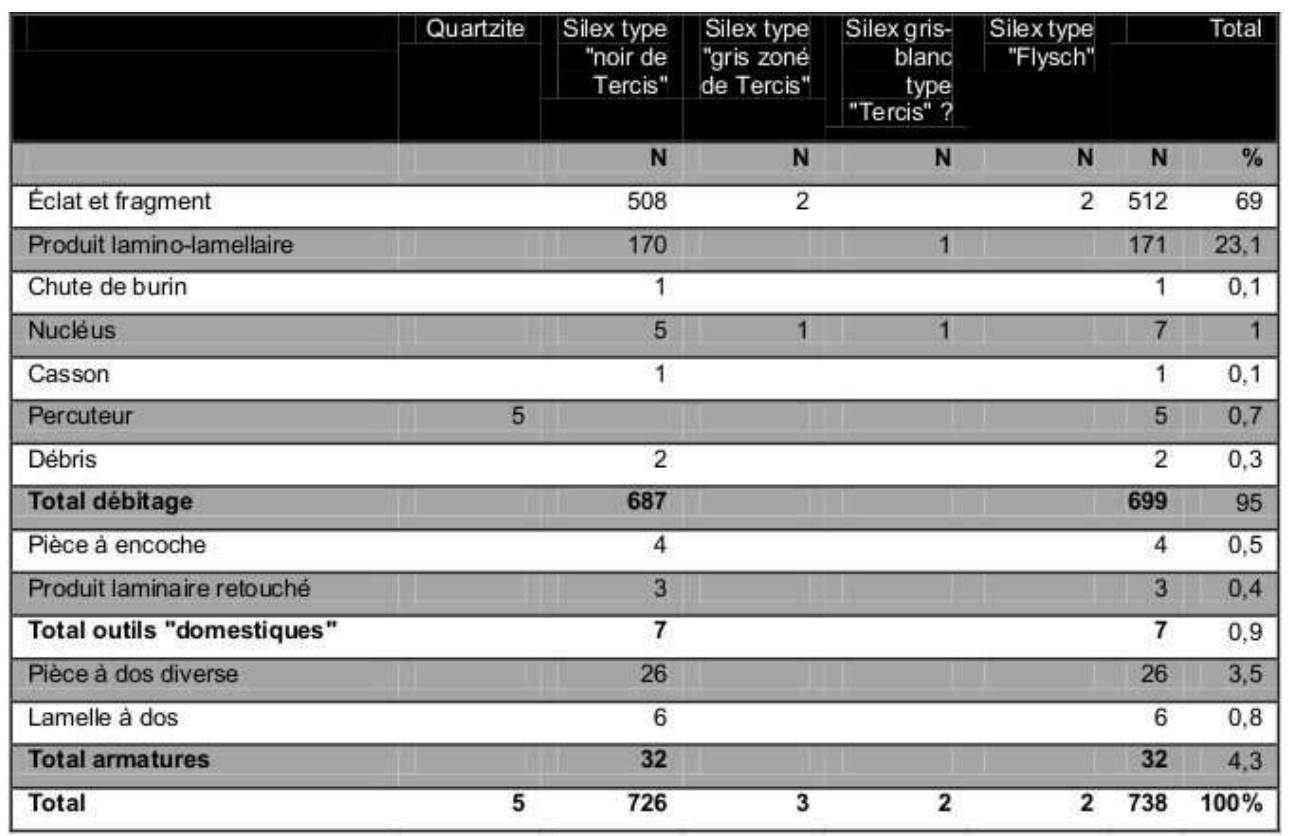

\section{3 - Projectiles}

Most of the 34 backed pieces display little technical investment (fig. 4 and 5). Generally speaking, the common denominator between these pieces is their atypical aspect. They are characterized by the absence of normative blank selection, which contrasts with classical Gravettian behavior. Indeed, rectilinear and regular blanks were generally selected for lithic projectiles with frequent correlation between the orientation of the point and the debitage axis of the blank, as shown by the Gravettian backed points from Isturitz, for example (Simonet 2010).

16 Moreover, in most cases, retouch is incomplete. Thus, these pieces in the process of being made do not seem to be functional. This is the reason why C. Normand advocated 
the hypothesis of apprenticeship when the pieces were discovered in the early 1980 s (Normand 1993). Only three backed bladelets stand out due to good blank quality, regular retouch and their dimensions (fig. $6-\mathrm{n}^{\circ} 1$ to 3 ).

On the other hand, the other backed pieces are either imperfect or unfinished. The heterogeneity of the blanks is striking, with poorly regularized or crooked blade sides (fig. $4-\mathrm{n}^{\circ} 1$ and fig. $5-\mathrm{n}^{\circ} 4,5,8,9$ ), laminar flakes (fig. $4-\mathrm{n}^{\circ} 7$ and 9 and fig. $5-\mathrm{n}^{\circ} 1,3$, $7,12,13$ ), a partial distal neo-crested blade (fig. $4-n^{\circ} 8$ ), a laminar flake (fig. $5-n^{\circ} 6$ ) and/or highly wavy debitage products (fig. $5-\mathrm{n}^{\circ} 2,10,11$ ). Ultimately, this blank diversity is the consequence of an economical choice as it reflects the use of waste products.

Apart from the three backed bladelets on rectilinear blanks with regular and parallel edges and ridges (fig. $6-\mathrm{n}^{\circ} 1$ to 3 ), only four pieces were made on relatively good quality blanks (fig. $4-n^{\circ} 2,4,5,6$ ). Among these, for two pieces the question arises of a link between the break and the fashioning of the back (fig. $4-\mathrm{n}^{\circ} 4$ and 6). These fractures could have occurred during debitage, before the back was made, in which case fragments of debitage products, rather than whole laminar products would have been selected for retouch. For one piece, although the blank is regular, it is very small in comparison to the average size of debitage products (fig. $4-n^{\circ} 5$ ). Lastly, only one quite rectilinear and regular piece is large in size with a thickness of $5 \mathrm{~mm}$ and a width of about $8 \mathrm{~mm}$ (fig. $4-\mathrm{n}^{\circ} 2$ ). Nonetheless, the blank is not issued from the full debitage phase as the scar of a removal perpendicular to the debitage axis is present on the upper surface.

Although all the blanks are poorly adapted to making backed pieces, they nonetheless reveal significant flint knapping experience. Some of the blanks of these backed pieces come from the extraction of blades to correct the arch and accentuate the convergence of the distal part of the debitage surface with the aim of creating naturally tapered debitage products (fig. $5-\mathrm{n}^{\circ} 4$ and 5). There are also removals geared towards redesigning the debitage surface (fig. $4-n^{\circ} 8$ and fig. $5-n^{\circ} 8$ and 9), a distal neo-crested flake to maintain longitudinal convexity (fig. $4-\mathrm{n}^{\circ} 8$ ) as well as the use of an opposed striking platform as shown by the removal scars opposite the upper surface of certain backed pieces (fig. $4-n^{\circ} 2$ and fig. $5-n^{\circ} 14$ ).

The contrast between the poor quality of the backed pieces and good knowledge of flint knapping principles represents the first of a series of divergences in this lithic assemblage. The selected blanks appear to be the worst products issued from laminar debitage requiring a high level of competence. Consequently, it seems paradoxical that the same people would make pieces destined to be transformed into backed pieces on one hand and then retouch the backs on poor quality pieces on the other hand.

21 These first data concerning lithic projectiles are consistent with the hypothesis that apprentices used waste debitage products. This hypothesis would also explain the discard of certain non-fragmented backed pieces (fig. $4-n^{\circ} 1,8$ and 9) and the presence of a piece that could patently never be used (fig. $4-n^{\circ} 8$ ). This postulate also explains the morphological diversity of the backed pieces : the gesture was of more importance than the finished object.

In a knapping workshop context beside a raw material outcrop, it is nonetheless more probable that flint was wasted by making atypical and/or non-functional pieces, and 
the interpretation of backed pieces as examples of apprenticeship for retouching backed pieces must be treated with caution.

Figure 4 - Backed pieces. Drawings A. Simonet.
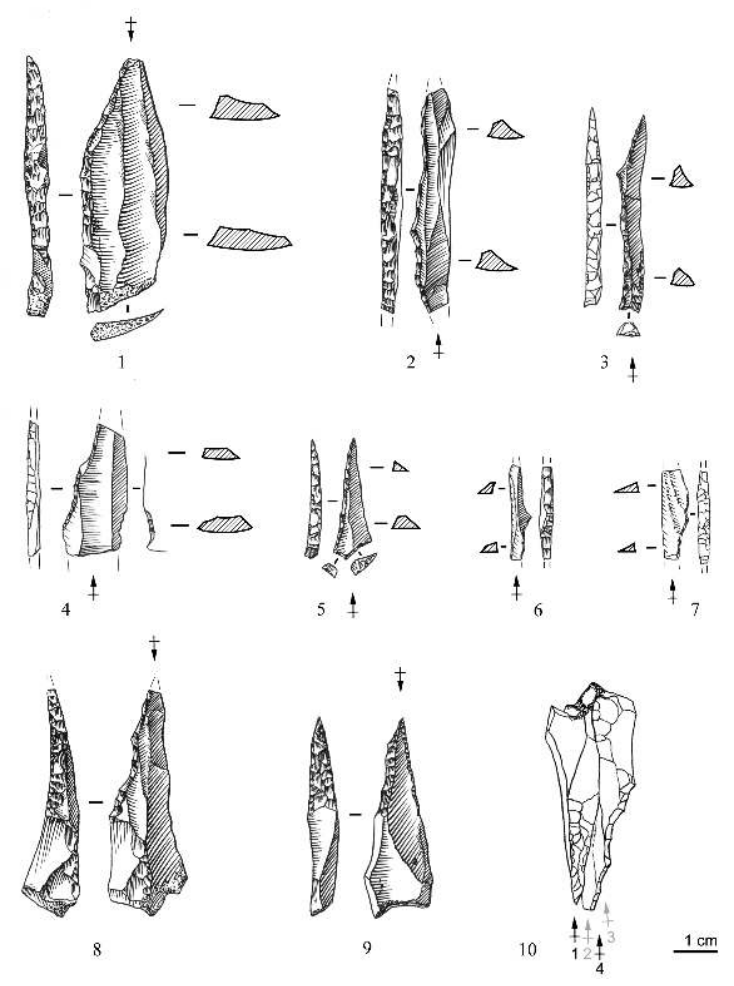

Figure 5 - Backed pieces. Drawings A. Simonet.
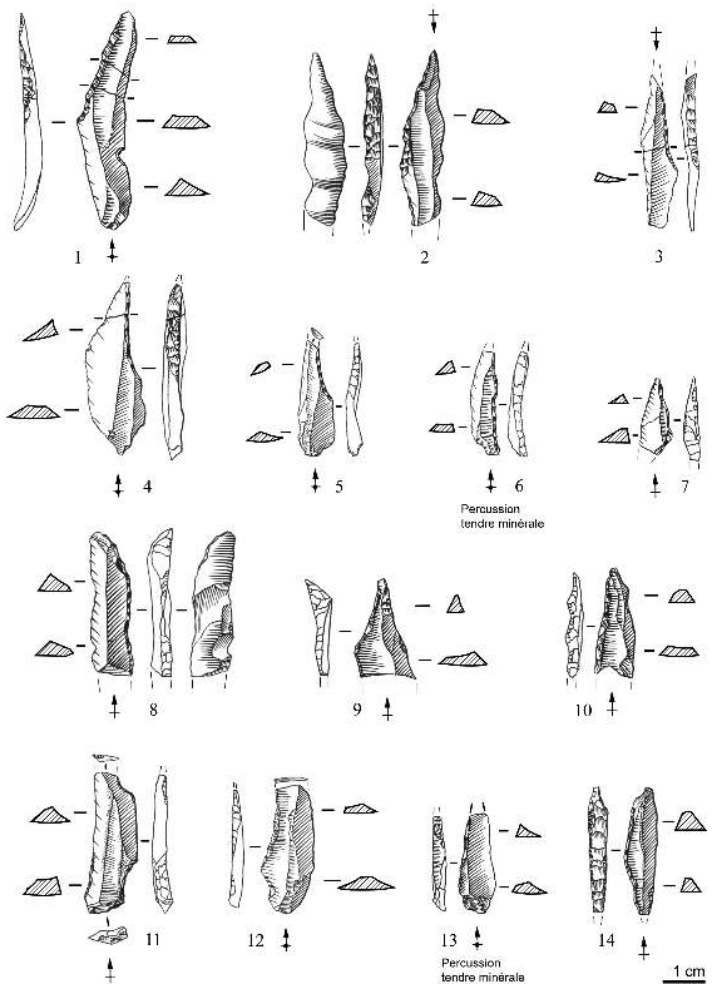
Figure 6 - Backed bladelets and backed micro-pieces. Drawings A. Simonet.

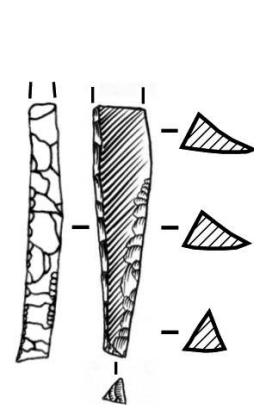

$\neq 1$

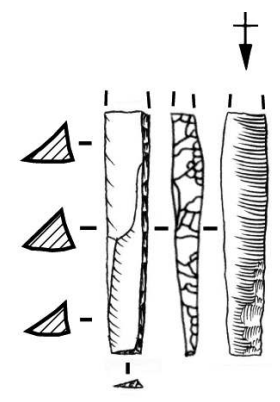

2

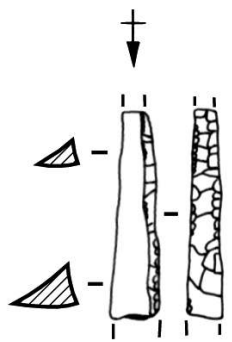

3

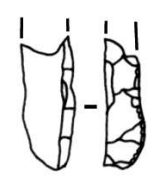

$+8$
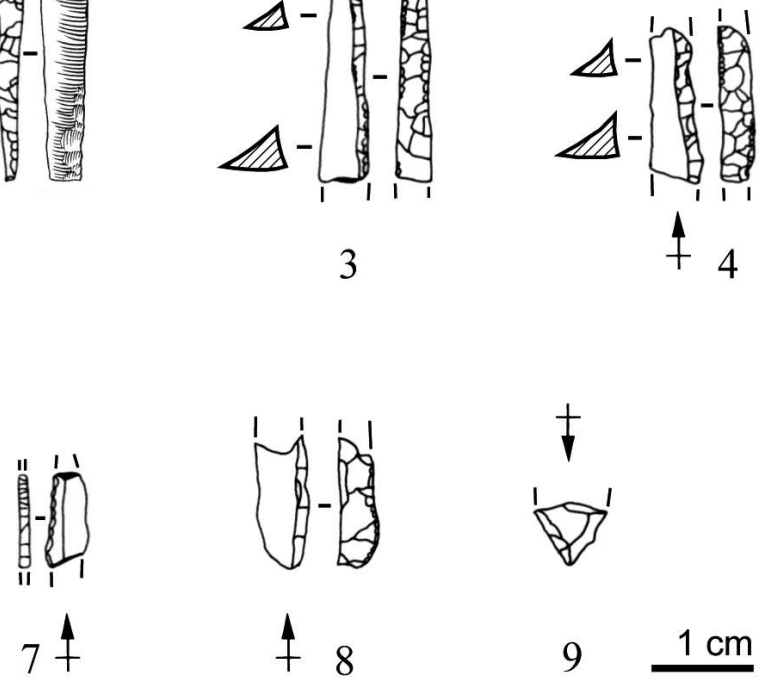

$7+$

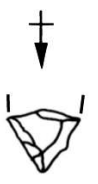

$9 \quad 1 \mathrm{~cm}$

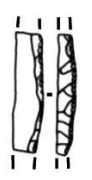

6

\section{4 - Cores}

$n^{\circ} 1$ is a prismatic well-made core with two opposed striking platforms and a very arched debitage surface about ten centimeters high (fig. 7). Perpendicular removal scars to the debitage surface axis suggest the use of anterior and posterior ridges. This piece is the only core made in grey-white, good quality, Tercis type flint, although it is not easy to identify it with precision. It is probable that the only laminar debitage product in an identical raw material comes from this core, although it does not refit (fig. $16-\mathrm{n}^{\circ} 5$ ). It is a crested blade knapped with soft mineral percussion. The significant length of the piece clearly distinguishes it from the complex of smaller laminar products in grey-black Tercis flint, as we will see below.

Core n. 2 has a bad keel and arch (fig. 8). The laminar surface is too flat and removals are resolved. The knapper created a lateral half crest (fig. $8-n^{\circ} 4$ ) without correcting the longitudinal distal convexity of the laminar surface. Because of this, the following removal also resolved (fig. $8-n^{\circ} 5$ ) and the core was abandoned. The presence of this slight prominence in the distal part of the debitage surface can be interpreted as a knapping error.

Core 3 is on a large piece of cortical debris (fig. 9). The extraction of the flake creating the striking platform simultaneously rid the core of the most unsuitable part. There was no prior shaping or striking platform preparation. However, the angle between the striking platform and the debitage surface is much too open (close to $90^{\circ}$ ) to produce laminar removals. Two bladelike removals were nonetheless extracted following long natural ridges. The first removal was probably cortical. The second removal resolved and the core was abandoned without yielding any exploitable products.

Core 4 is on a small $7 \mathrm{~cm}$ flake (fig. 10). After opening up a striking platform and slight overhang abrasion preparation, debitage of small laminar products began on the right 
and progressively reached the side of the flake. During the first stage, at least four laminar products (fig. $10-\mathrm{n}^{\circ} 3_{1}$ to $3_{4}$ ) were extracted using semi-rotating removals which flattened the laminar surface. The arch became too open and the two laminar flakes then removed by soft mineral percussion and refitted on the core resolved (fig. $10-\mathrm{n}^{\circ} 4_{1}$ and $4_{2}$ ). The broken distal part of the penultimate laminar removal refitted on the core was outrepassé whereas the last removal before the core was abandoned resolved (fig. $10-n^{\circ} 5$ ).

Core 5 is on a small oval-shaped block of rolled and frost-shattered flint, about $10 \mathrm{~cm}$ long (fig. 11). This small block was broken in two (fig. $11-\mathrm{n}^{\circ}$ ), then one of the $6 \mathrm{~cm}$ long fragments was used as a core. Three partly cortical laminar removals were extracted (fig. $11-\mathrm{n}^{\circ} 2$ ', $2_{1}$ and $2_{2}$ ). These were followed by a laminar product just beneath the cortex (fig. $11-\mathrm{n}^{\circ} 3$ ) and a last resolved laminar product which were both refitted fig. $\left.11-\mathrm{n}^{\circ} 4\right)$. The butt presents traces of slight abrasion preparation.

Core 6 is a prismatic core, about $10 \mathrm{~cm}$ long, with two opposed striking platforms (fig. 12 and 13). It was probably knapped on a small block. Several laminar products were refitted by C. Normand and S. Dartiguepeyrou. They appear to have been extracted using soft mineral percussion. This core was elaborately prepared compared to other cores with the probable preparation of a posterior crest (fig. $12-\mathrm{n}^{\circ} 1$ ) and a two-sided anterior crest (fig. $12-\mathrm{n}^{\circ}$ 2). The frontal debitage allowed for the extraction of laminar products about $8 \mathrm{~cm}$ long. About ten laminar products were probably extracted before the last refitted examples on the core (fig. $12-\mathrm{n}^{\circ} 3$ and 4). In chronological debitage order, the first laminar refitted product is a crested blade (fig. $12-\mathrm{n}^{\circ} 5$ ). Like for core 2 , a distal bulge of the laminar surface hampered the extraction of the following bladelike products which resolved (fig. $13-\mathrm{n}^{\circ} 6_{1}$ to $6_{3}$ ). The knapper later tried to correct these resolved removals with a partial neo-crest, by the extraction of laminar product $6_{4}$. However, flint heterogeneity induced strong undulations which complicated debitage. With such poor quality flint the knapper could hardly improve the state of the debitage surface. He thus decided to knap the right hand side (fig. $13-\mathrm{n}^{\circ} 8$ ) after slight correction of the keel using striking platform 2 (fig. $13-n^{\circ} 7$ ). The four laminar products extracted from striking platform 1 resolved in spite of preparing a partial distal neo-crest, probably between removals $8_{3}$ and $8_{4}$. Still with striking platform $n^{\circ} 1$, the knapper came back to the initial frontal debitage axis in order to extract laminar products $9_{1}$ to $10_{2}$. Only removal $9_{2}$ is missing. The two last removals $10_{1}$ and $10_{2}$ resolved (fig. 13). The core was finally abandoned with a very rugged debitage surface.

Core 7 looks like a double burin on a truncation but it is clearly a core about $10 \mathrm{~cm}$ long on a flake profile (fig. 14). The blank is an old flake in grey streaked Tercis flint, as shown by the patinated and rolled surface. The flint is deeply altered and of poor quality. The preparation of the flake occurred on site, at least partially, as shown by the two refitted flakes (fig. 14). The two lateral sides of the blank were summarily knapped into a crest with one side sloping towards the upper face and a striking platform and a laterally sloping striking platform with a rather careless truncation. At least four subparallel removals were extracted from one of the sides, the longest being about $5 \mathrm{~cm}$ long, but all of them are resolved.

Cores 8 and 9 were not found but a refit of most of the shaping elements and part of the blade debitage yields the negative image of the cores (fig. 15). An $18 \mathrm{~cm}$ nodule of black Maastrichtian Tercis type flint was used. After a roughing-out stage and the elimination of the frost-shattered zone (fig. $15-n^{\circ} 1$ to 9 ), the removal of a large flake 
(fig. $\left.15-n^{\circ} 10\right)$ fractured the block into two, perhaps intentionally. Two cores on flake sides, about $8 \mathrm{~cm}$ high, were then prepared. Core A is unipolar and yielded blade products ranging from six to seven centimeters long (fig. 15). A lateral neo-crest was prepared in order to maintain a very closed arch. The debitage is frontal and narrow on the side of a flake with products alternating from the right to the left in relation to the central axis of the debitage surface, thus maintaining a satisfactory arch (fig. 15). Soft mineral percussion seems to have been used for all the blade products and the overhang was prepared by abrasion. Core B presents the same blade debitage on the side of a flake but with two hierarchized striking platforms. The economic return on these cores is moderate. Only one blade product is missing from the refit (fig. 15 $\mathrm{n}^{\circ} \mathrm{A}_{16}$ ). This product was well made and could have been selected and brought elsewhere. The block was of rather poor quality (a large frost-shattered zone) rendering higher productivity unrealistic.

Generally speaking, the cores are in poor quality raw materials (cores 3, 5, 6, 7). In a context of abundant good quality blocks, given the various flint outcrops available and the significant number of objects gathered from the site since the $19^{\text {th }}$ century, it is particularly strange that the knappers only selected small, rolled, altered or frostshattered blocks. The exploitation of these blocks cannot be interpreted as a result of difficult good quality raw material procurement. When the quality of the flint is better (cores 3 and 4), the blanks used for the cores are too small for backed point fabrication. The knapped products have no functional vocation as most of them have been refitted onto the cores. This debitage thus has no economic potential and the blanks issued from these cores appear to have been selected for their unproductive nature. Only core 1 was productive. This is also the only core for which the debitage products were not found.

As for operating modalities, only core 1 displays complex debitage and could clearly not have been produced by an apprentice knapper (fig. 7). Cores 8 and 9 may also have been exploited by one or several competent knappers given the diversified arching and keeling procedures involved: distal primary neo-ridge, lateral neo-crest, second rectified striking platform, debitage rhythm with alternating removals on either side of the median axis in order to conserve a good arch (fig. 15). Core 6 is an equivalent case (fig. 12 and 13). All of the technical aspects are mastered (arching, lateral crest, second rectified striking platform). The irregularity and the twisted nature of the products may just as easily be interpreted as the consequences of a poor quality raw material as a result of the knapper's awkwardness. The only possible error is the delayed use of a second striking platform to correct the keel. The selection of a poor quality raw material, which can generally be interpreted as one of the criteria for identifying an apprentice knapper, is particularly problematic here. Paradoxically, a good quality flint reveals the knappers' errors without having to take account of the adaptation and the constraint of the raw material.

That leaves cores 2, 3, 4, 5 and 7 which were not shaped and which only produced several small, poor quality blanks each (fig. $8,9,10,11,14$ ). Core 5 is undoubtedly the most interesting case with regard to the apprentice knapper notion : the quality of the flint is not adapted to blade debitage and the knapper clearly knew that no useable blank would be produced (fig. 11). 
Figure 7 - Laminar core $n^{\circ} 1$ with highly arched debitage surface and two striking platforms. Drawing A. Simonet.

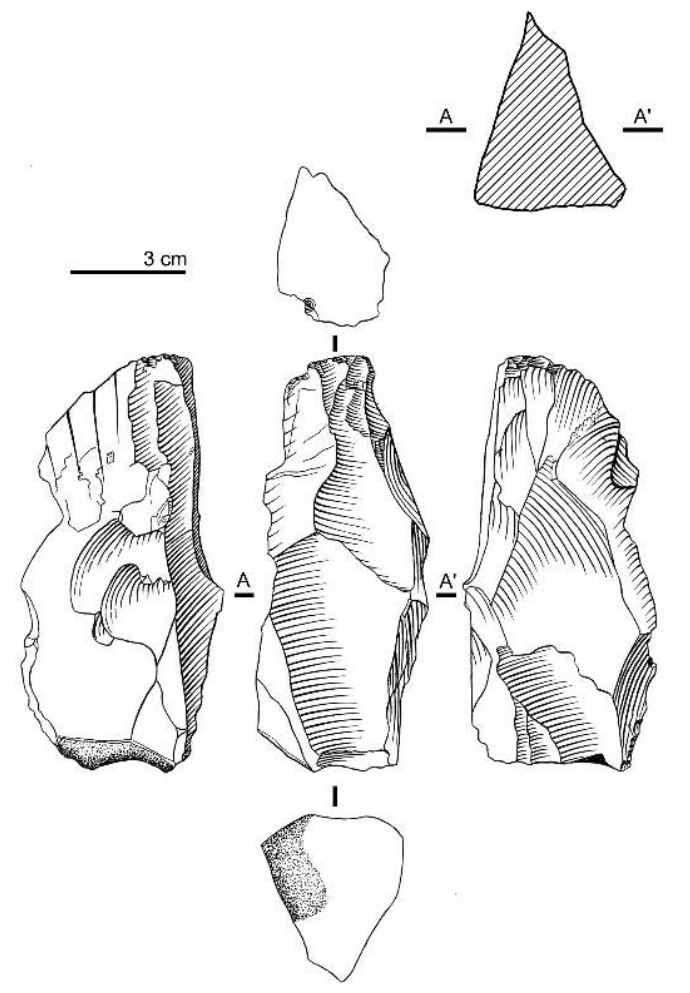

Figure 8 - Core $n^{\circ} 2$ with 5 refitted products. Drawings A. Simonet.
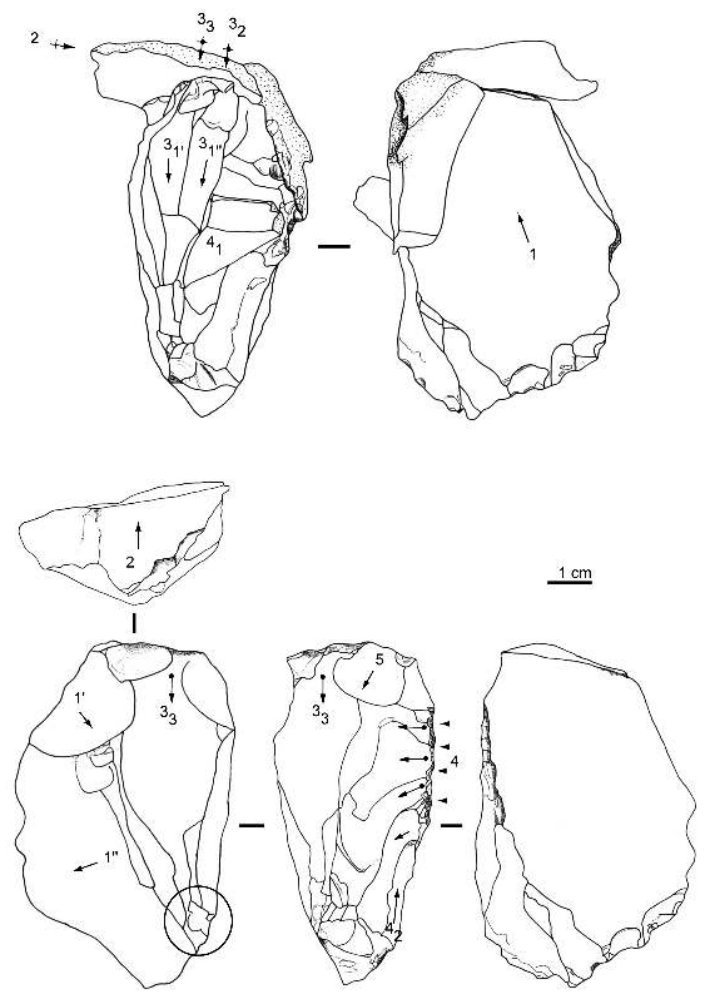

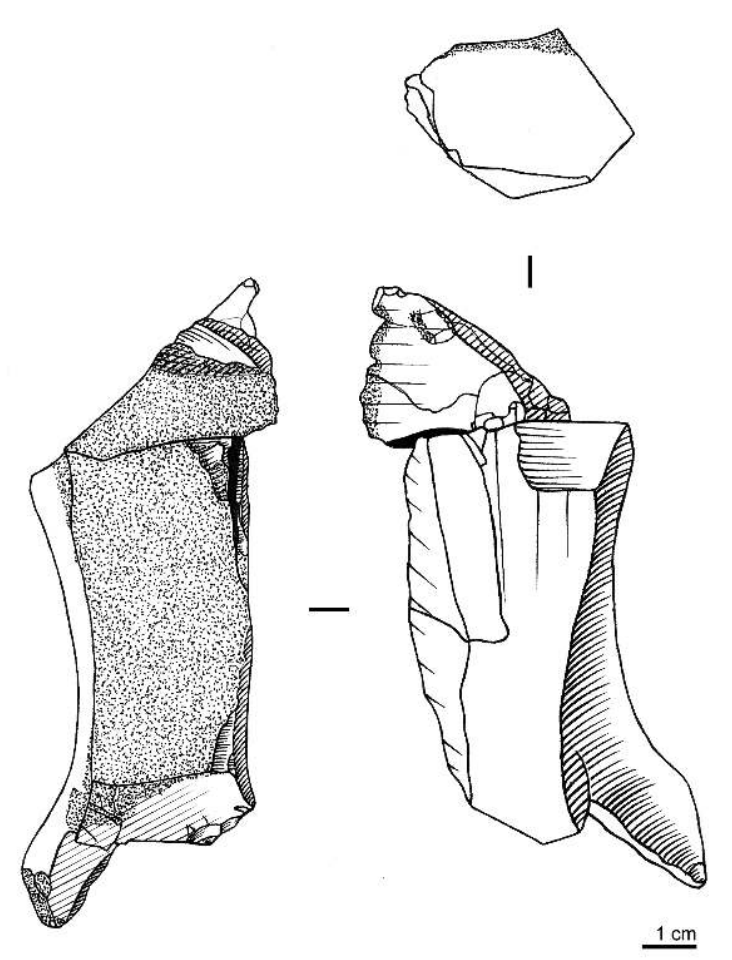

\section{5 - Debitage products}

Debitage products include numerous laminar blanks (fig. 16). Excluding the products refitted onto cores, there are 111 whole and fragmented blade products. Among these, 37 pieces are whole, which corresponds to a third of all products. Eighteen connecting pieces bring the number down to 102 pieces (tab. 2). Generally speaking, these products bear slight or no patina but several pieces display a developed patina and 18 a slight patina. All these pieces are in black Maastrichtian Tercis flint, apart from a large blade product in grey streaked Tercis flint (fig. $16-n^{\circ} 5$ ). Among the 62 whole or broken pieces corresponding to products from the full debitage phase, 17 are whole (fig. $16-\mathrm{n}^{\circ}$ 1 to 4). Most of the products are rectilinear but the regularity of the edges and the ridges is mediocre. Only four whole good quality blade products convey an image of what knappers were aiming for (fig. $16-\mathrm{n}^{\circ} 1$ to 4 ).

The lengths of the blade products are generally between six and seven centimeters (fig. 17). Leaving aside the trimming products (crested ridge flake, side blades, debitage surface removals) in order to gain a clearer idea of the targeted products, the 62 blade products and fragments present a width varying between 15 and $20 \mathrm{~mm}$ for a thickness of 4 to $6 \mathrm{~mm}$ (fig. 18). Only the grey streaked blade is clearly different from the rest of the series, with a length of 12 centimeters (fig. $16-n^{\circ} 5$ ).

Rectifying and trimming products, such as 12 curved and twisted side products, often with oblique butts, about fifteen primary and lateral neo-crested products and three slightly plunging debitage surface removals, show the use of varied methods for maintaining an arched and rectilinear debitage surface (fig. $16-\mathrm{n}^{\circ} 6$ and 7). There are also about fifteen blade products with opposed removal scars evoking the use of a 
second striking platform (fig. $16-\mathrm{n}^{\circ} 6$ ). In fact, all of the blade products converge towards the identification of a unique chaîne opératoire geared towards the manufacture of small rectilinear and regular blades from very arched unipolar or bipolar cores.

Out of 67 blade products where it is possible to study the percussion mode from the butt, 44 products bear clear signs of soft mineral percussion as shown by developed butt abrasion, the presence of a reduced impact point, specific scarring of the bulb and the frequent presence of fine, tight lines on the bulb surface (fig. 19), (Pelegrin 2000). Overhang abrasion on these blade products is more insistent than on products refitted onto cores.

Figure 10 - Core $\mathrm{n}^{\circ} 4$ with 3 refitted products. Drawing A. Simonet.
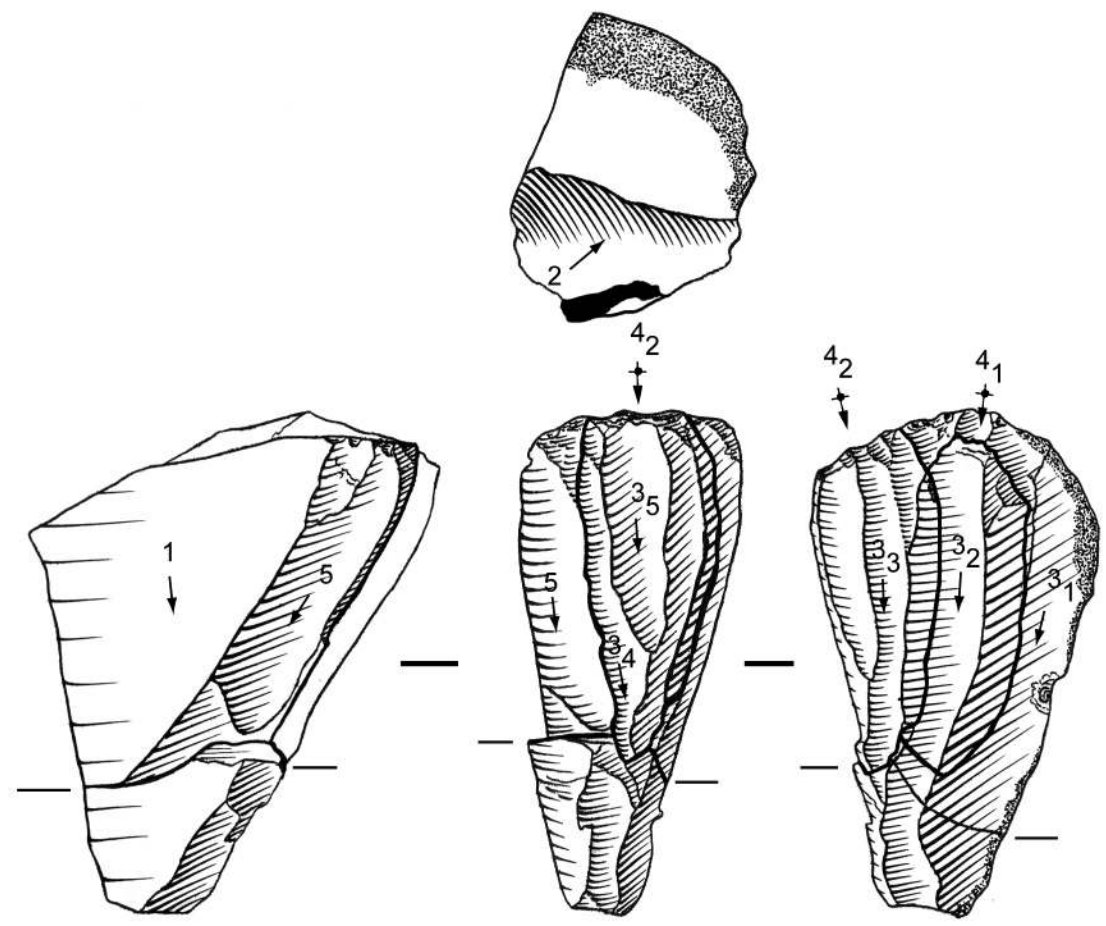

$1 \mathrm{~cm}$ 
Figure 11 - Core $n^{\circ} 5$ with 3 refitted products. Drawings A. Simonet.
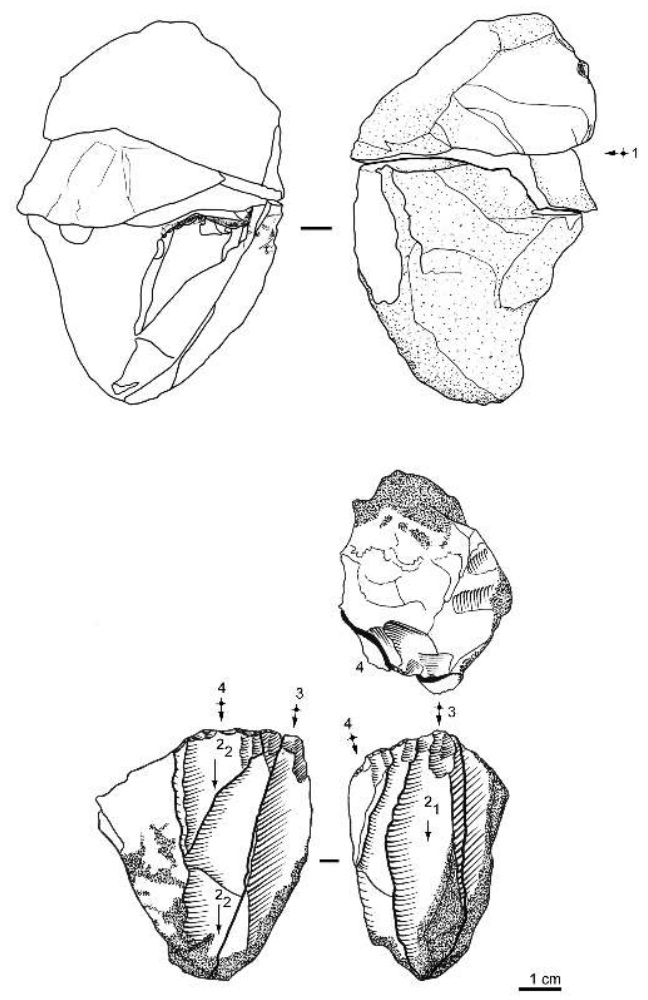

Figure 12 - Core $n^{\circ} 6$ with 15 refitted products. Drawing A. Simonet.
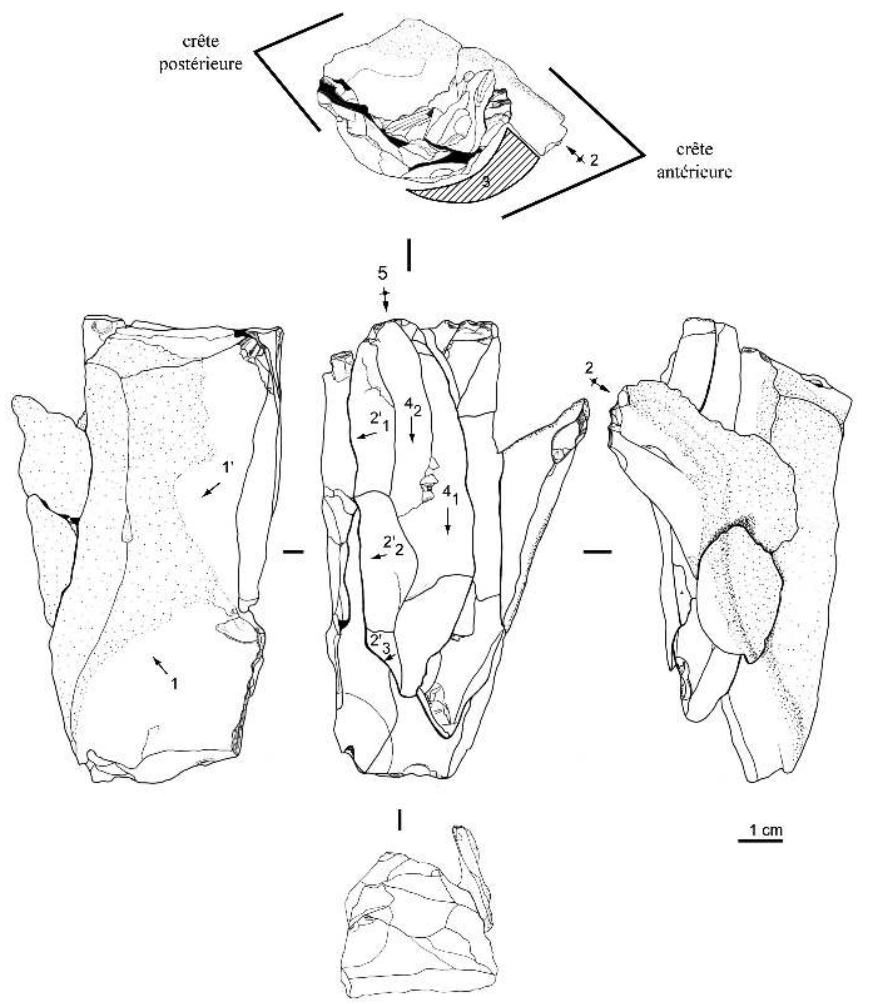
Figure 13 - Progressive dismantling of the refitting of core $n^{\circ} 6$. Drawings A. Simonet.

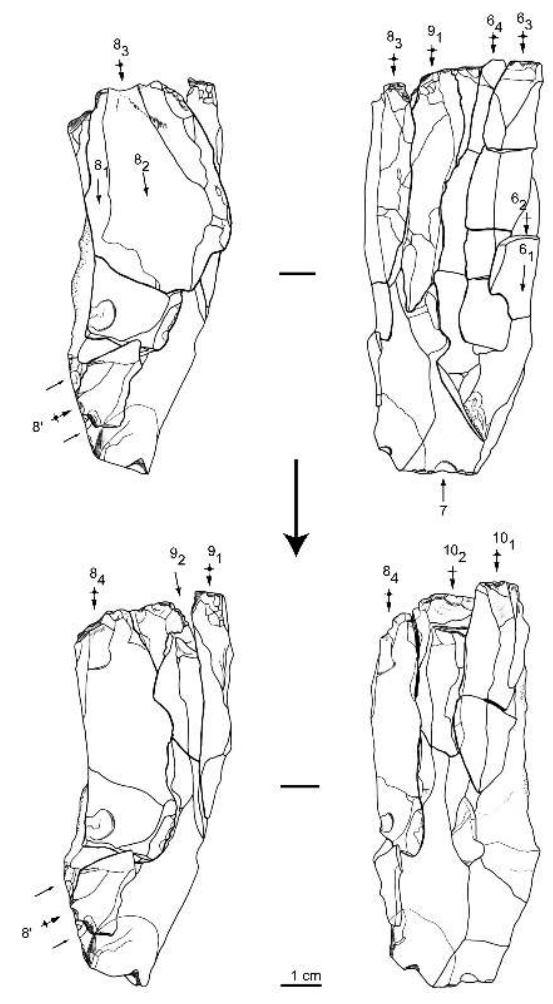

Figure 14 - Core $\mathrm{n}^{\circ} 7$ with 2 refitted products. Drawing A. Simonet.
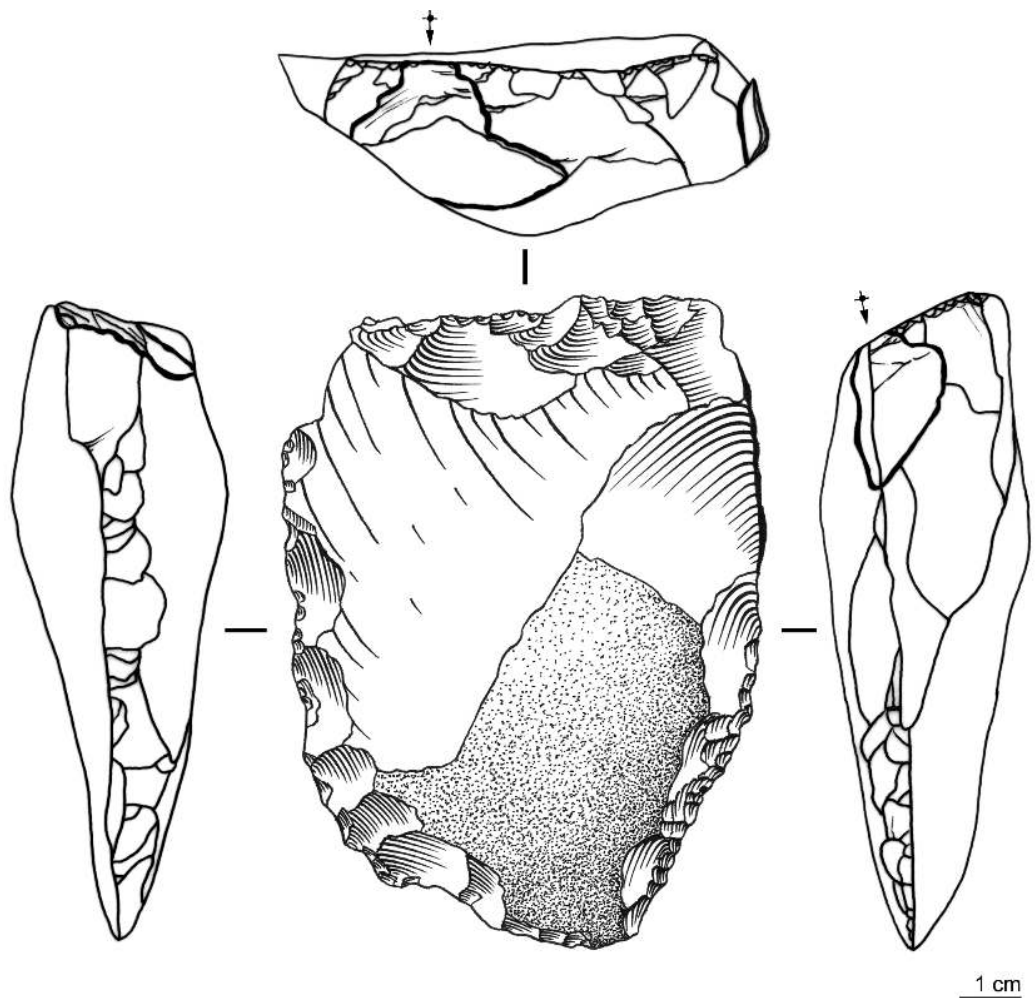
Figure 15 - Refitting of 40 non-retouched products. Photograph A. Simonet.

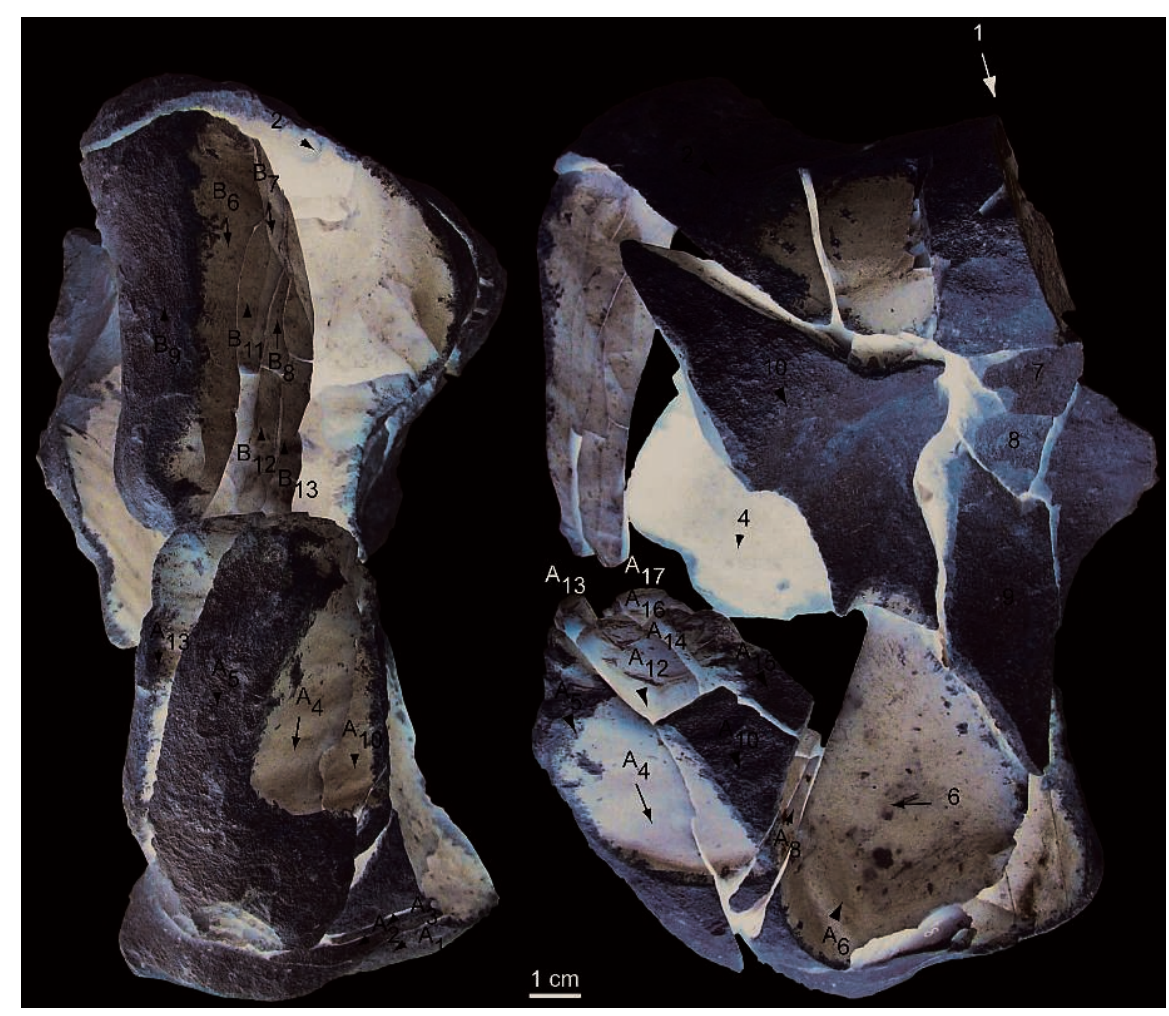

\section{3 - An example of backed projectile apprenticeship?}

\section{1 - The contradictions of the chaîne opératoire}

The first contradiction of this series concerns the dominant exploitation of a poor quality rolled or frost-shattered raw material in one of the best outcrop contexts in Chalosse.

Moreover, two types of exploitation have been observed: the exploitation of good quality blocks yielding well made products, as shown by cores 1,8 and 9 as well as most of the blade products (fig. 7,15 and 16). On the other hand, the other cores and refitting products show the complementary on-site exploitation of poor quality blocks or flakes for which most of the elements of the chaîne opératoire have been found, and have yielded less prepared bladelike flake products (fig. 8 to 14). The difference between the six refitted cores and the regular blade products in good quality flint is incontestable, especially considering the fact that these discarded products are of poor quality.

This poor quality production is also apparent for blanks transformed into backed pieces (fig. 4 and 5). The worst blanks were systematically selected whereas certain better quality blade products were not transformed (fig. 16).

The only productive core with complex operative modalities is core 1 . This is the only core in good quality grey-white flint and the only core with no refitting blanks (fig. 7). Only one blade in the same raw material was collected, probably from this core (fig. 16 $-n^{\circ} 5$ ). It is exceptionally large and extremely well made. Why were these two pieces isolated? They were probably exploited at another part of the Tercis site or in a destroyed zone. 

issued from the exploitation of the same block of black Tercis flint? Were they exported? The cores which produced blade products of relatively good quality are also absent (fig. 16).

This series associates backed pieces with several almost fully refitted cores. Consequently, we can affirm that the backed pieces were not made on products issued from core exploitation. Given that the backed pieces are waste products from complex blade debitage, everything tends to show that they were made on blanks issued from productive cores which are not present in this part of the concentration.

Lastly, these backed pieces are of poor quality, like the refitted cores, and contrast with the quality of certain blade products, core 1 and missing cores, which require a high level of competence. Why did the knappers make the backed pieces when they knew before transforming the back that certain of these pieces could not be used ? The same question is relevant for most of the cores.

Table 2 - Count of non-retouched laminar products (excluding refits).

\begin{tabular}{|l|c|}
\cline { 2 - 2 } \multicolumn{1}{c|}{} & $\mathbf{N}$ \\
\hline Lame à pan cortical & 2 \\
\hline Lame sous-crête & 4 \\
\hline Lame de plein dèbitage & 62 \\
\hline Lame de recintrage & 12 \\
\hline Enlèvement de table & 3 \\
\hline Nèo-crête mèdiane & 13 \\
\hline Nèo-crête latėrale & 2 \\
\hline Ėclat laminaire (mise en fome ou entretien) & 4 \\
\hline Total & 102 \\
\hline
\end{tabular}

\section{2 - The apprenticeship hypothesis}

Taken separately, none of the aforementioned points represents an objective criterion for affirming knapping apprenticeship. Different causes can have the same consequences : an urgent need requiring no complex shaping associated with a poor quality raw material, tests carried out by an experienced knapper to warm up before beginning debitage on quality raw materials, or the consequences of a simple game... Nonetheless, the evidence present in this assemblage points to a solid basis for advancing the hypothesis of an apprentice workshop for backed lithic projectiles (fig. 20) :

- Petrographic data: did competent knappers select poor quality flint and waste products for apprentices to practice making rectilinear blades and backed pieces without wasting good quality flint?

- Economic data: only one core was productive. Five cores only yielded two or three irregular laminar products whereas three cores provided about ten irregular blade products each. Most of these blade products were not used.

- Technological data: on a smaller scale adapted to the poor quality raw material, these cores reproduce the Gravettian concept of debitage based on an exploitation of two hierarchized striking platforms and an arched debitage surface aimed towards the production of rectilinear products. The study of non-transformed blade products shows that the targeted 
type is unique. These are very standardized rectilinear blades about $60 \mathrm{~mm}$ long, 15 to 20 $\mathrm{mm}$ wide and $5 \mathrm{~mm}$ thick. This model corresponds exactly to that necessary for making a backed point. On the other hand, the modalities are simplified and the maintenance and rectifying operations of the debitage surfaces are not always adapted to circumstances. These debitage represent poor quality versions of those present in the nearby major Gravettian sites of Brassempouy and Isturitz.

- Spatial data: non-collected quality exploitation was carried out beside an adjacent concentration or in a different zone of this same concentration. Given that these pieces were found in the peripheral zone of the workshop, it is possible that a more careful debitage was carried out at the center of the concentration. Core 1 and its blade, as well as all the good quality blade products which could not be knapped in the cores present in the series are the only proof of this. We have only slight evidence of differential spatial distribution of activities depending on competence levels.

- Educational data: core 1 and its unique blade may have been used as a model to guide apprentices. These objects would have been used as examples to be copied.

Figure 16 - Non-retouched laminar products. Some products, better manufactured than the blanks used for the backed pieces, were not retained. Drawings A. Simonet.
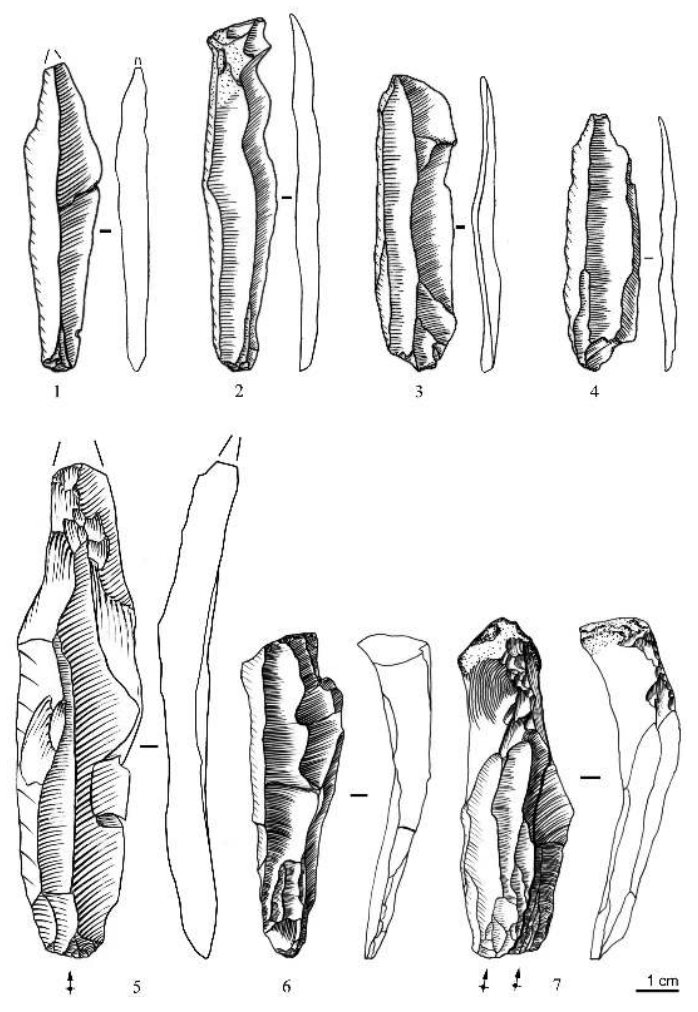
Figure 17 - Length of non-retouched laminar products in black flint from Tercis.

Effectif

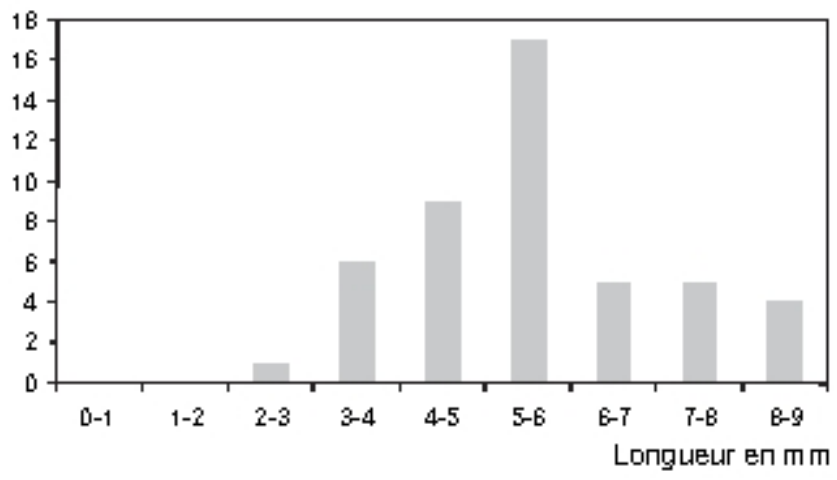

Figure 18 - Width/thickness ratio of the 62 full debitage non-retouched laminar products in black flint from Tercis.

Ėpaisseur en mm

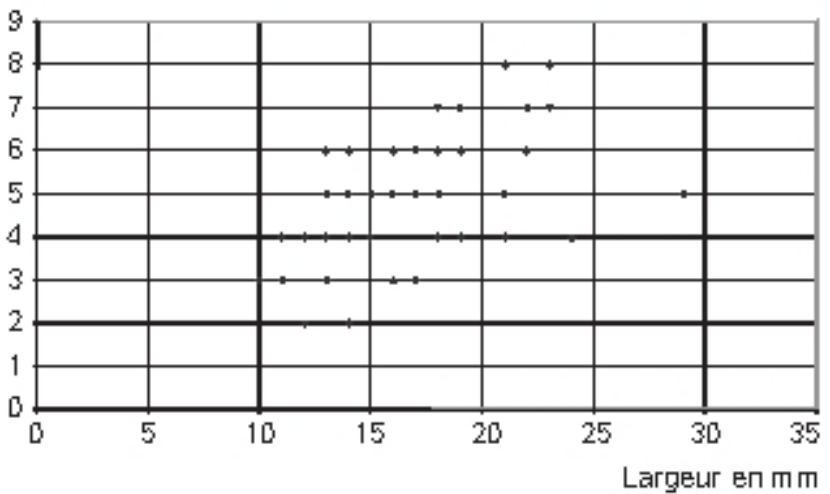


Figure 19 - Full debitage non-retouched laminar products with diagnostic evidence of soft mineral hammer use. Photograph A. Simonet.
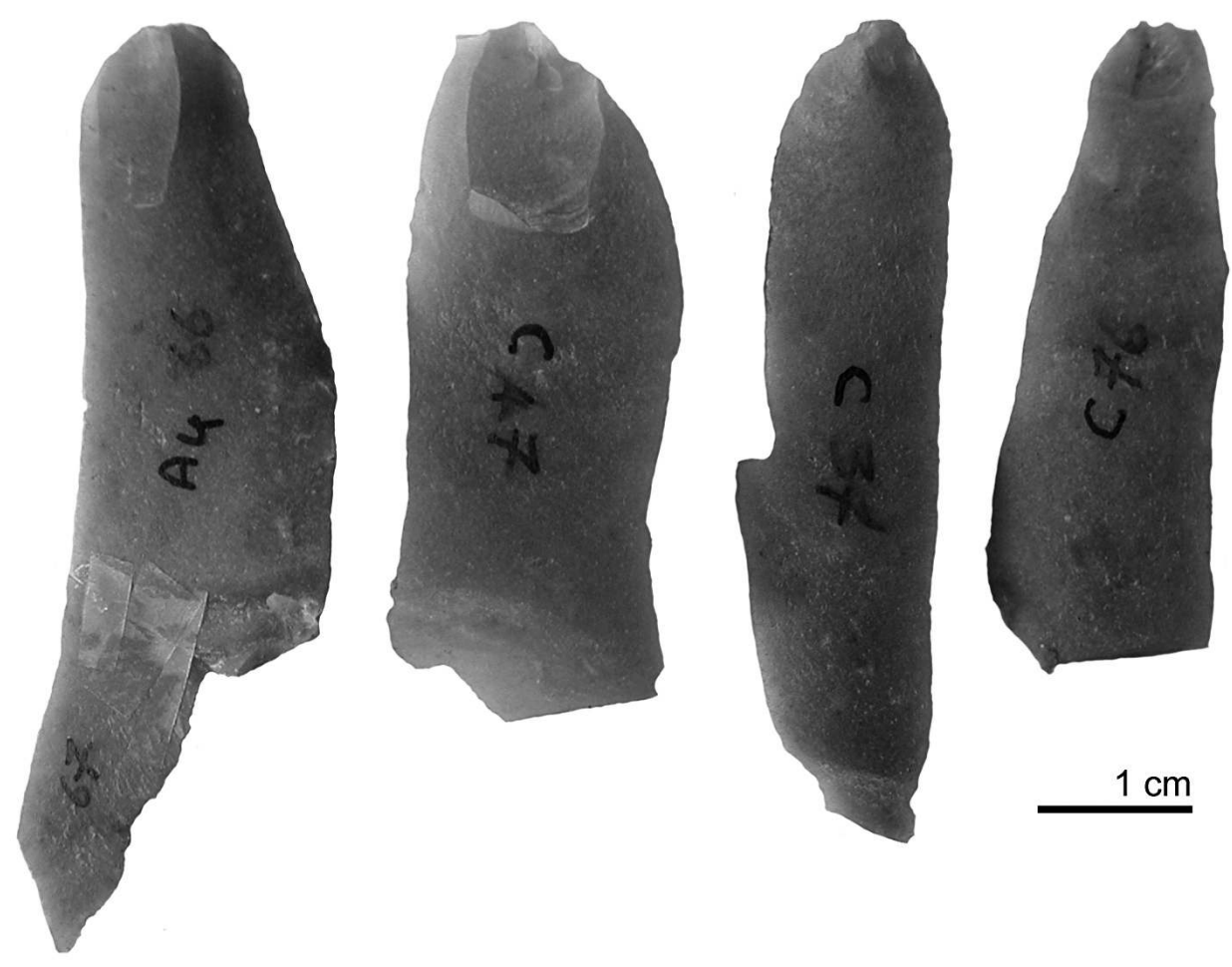

\section{4 - Conclusion and research perspectives}

\section{1 - Tercis and the regional Gravettian context}

It is remarkable that no equivalent badly made backed pieces have been found in the Gravettian at Isturitz or in Chantier I at Brassempouy (Simonet 2009, 2010, 2011, 2012). The fact that Isturitz cave was excavated a long time ago could to some extent, explain this absence, but the first series of sieving have not revealed any signs of projectile making by apprentices. Conversely, the first data from the Gravettian knapping workshop of Mugarduia Sur, in Spain, corroborates the existence of greater variability in chaînes opératoires at sites specialized in flint knapping (Barandiarán et al. 2007 ; Simonet 2009). This satellite site for the major Gravettian camps of Brassempouy and Isturitz is the only site, with Tercis, which presents a significant number of backed pieces which do not slot into Gravettian Pyrenean typology (Simonet 2010). Consequently, the absence of similar awkward backed pieces to those of Tercis in Isturitz and Brassempouy caves points towards a sociological interpretation. According to this hypothesis, apprenticeship would be spatially limited to certain contexts, such as raw material outcrops. Pending new observations, we suggest interpreting the Tercis series, discovered by C. Normand, as one of the oldest discovered traces of apprenticeship of lithic projectile making between 29,000 and 22,000 years before the present (fig. 20). This apprenticeship hypothesis has strong palaeo-sociological implications as it provides a supplementary parameter for attempting to describe the complex management of the Pyrenees territory by Gravettians (Lacarrière et al. 2011 ; Redondo 2011 ; Simonet 2009, 2012). 
Figure 20 - Tercis (Landes, France): Gravettian archaeological remains of supervised apprenticeship activities in a knapping workshop more than 22000 years ago? Drawing A. Simonet.

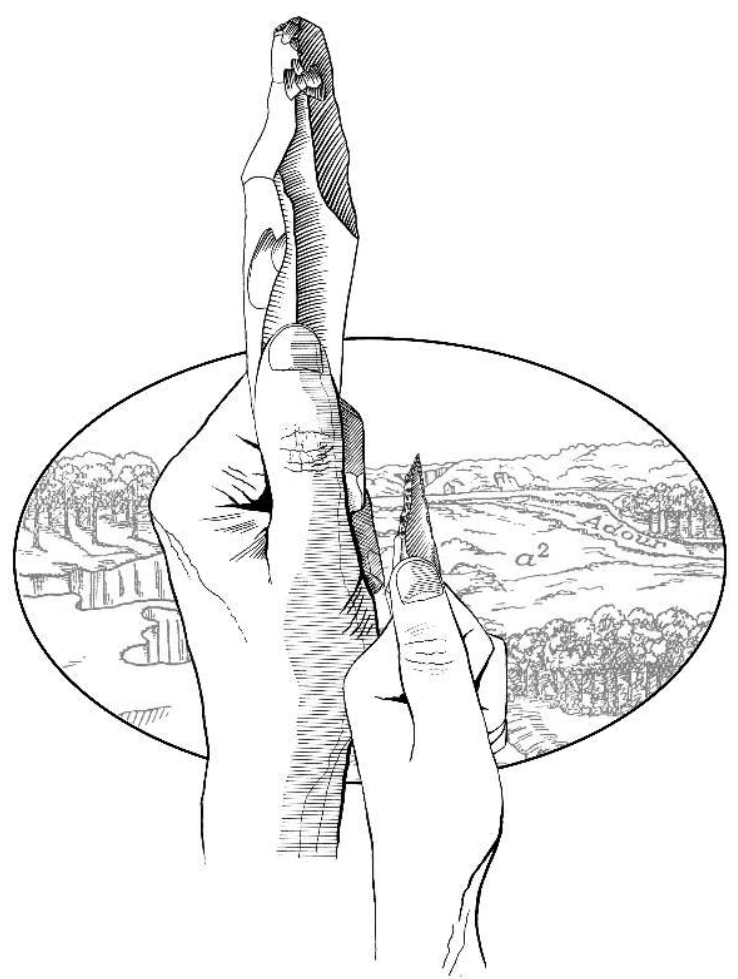

We wish to thank C. Normand who entrusted us with studying this series for our Maitrise dissertation and who shared his knowledge of the Tercis site with us. We also thank F. Bon who supervised and corrected this university research.

\section{BIBLIOGRAPHY}

\section{2 - Tercis and the European Gravettian context}

Flint knapping apprenticeship raises the question of the role of children and adolescents in Gravettian societies. The Tercis data are part of a coherent complex of chronological and geographic evidence from Gravettian societies or societies contemporary with the Gravettian. This evidence shows that during the Upper Palaeolithic, young people are included in social practices at an early age. The Pyrenean cave of Gargas, for example, contains representations of handprints indicating that children used the cave and participated in certain rites (Foucher et al. 2007). In the Czech Republic, the study of dermatoglyphs preserved on clay statuettes from Dolní Věstonice suggests that some of these pieces were modeled by ten-year-old children (Kralick \& Novotny 2005). But the most interesting documentary source is undoubtedly that of primary burials, which combine biological and cultural data (Henry-Gambier 2008). The analysis of 
anthropological documentation reveals new behavior in the European Upper Palaeolithic from the beginning of the Gravettian onwards : intentional primary deposits for deceased children, from the perinatal stage to adolescents. It is noteworthy that there are children's burials contemporary with the Gravettian in Sungir and at Mal'ta (Bader 1998 ; Cauwe et al. 1996 ; Derevianko et al. 1998). This evidence could point to changes in social organization during the Gravettian where young people began to play an increasingly important role in society compared to the earlier Aurignacian.

ARAMBOUROU R. 1963 - Essai de paléogéographie du Paléolithique des Landes, Thèse complémentaire pour le Doctorat ès Sciences, Université de Bordeaux I.

BADER N. 1998 - Upper Palaeolithic site Sungir (graves and environment), Moscou, Scientific World, $270 \mathrm{p}$.

BARANDIARÁN I., BENEITEZ P., CAVA A., MILLÁN M. A. 2007 - El taller gravetiense de Mugarduia sur (Navarra) : identificación y cronología, Zephyrus, 60, p. 85-96.

BODU P. 1994 - Analyse typo-technologique du matériel lithique de quelques unités du site magdalénien de Pincevent (Seine-et-Marne). Applications spatiales, économiques et sociales, Thèse de doctorat de l'Université de Paris I Panthéon-Sorbonne. 3 vol.

CAUWE N., MEDVEDEV G., LIPNINA E., CLAES L., COUPE D., MODRIE S., MUXHARRAMOV S., OSADTSHY S., PETITT P., REBRIKOV P., ROGOVSKOÏ E., SULERJITSKY L., VOROBEVA G., XHENZIXHENOVA D. 1996 - Mal'ta en Sibérie : Présentation du programme de recherche des Musées royaux d'Art et d'Histoire de Bruxelles et de l'Université de l'Etat à Irkoutsk, Anthropologie et préhistoire, Bruxelles, Société royale belge d'anthropologie et de préhistoire, vol. 107, p. 109-130.

DAGUIN F. 1948 - L'Aquitaine occidentale, Géologie régionale de la France vol. 5, dir. Albert F. de Lapparent, Actualités scientifiques et industrielles 1050, Hermann \& Cie, Paris, 232 p.

DEREVIANKO A.P. et al. Ed. 1998 - The Paleolithic of Siberia : new discoveries and interpretations, Urbana, University of Illinois Press, 406 p.

DU BOUCHER H. 1877 - Les Aquenses primitifs ou Dax avant l'Histoire, Bulletin de la Société de Borda, p. 273-288 et 423-437.

DU BOUCHER H. 1878 - Quelques nouvelles trouvailles préhistoriques landaises, Bulletin de la Société de Borda, p. 56-61.

DU BOUCHER H. 1879 - Matériaux pour un catalogue des stations préhistoriques landaises. Bulletin de la Société de Borda, p. 307-317, Matériaux pour l'histoire primitive et naturelle de l'Homme, volume 14 , série $\mathrm{n}^{\circ} 2$, tome $\mathrm{X}$, p. 258-270.

FOUCHER P., SAN JUAN-FOUCHER C., RUMEAU Y. 2007 - La grotte de Gargas. Un siècle de découvertes, Édition Communauté de communes du canton de Saint-Laurent-de-Neste, 128 p.

HENRY-GAMBIER D. 2008 - Les sujets juvéniles du Paléolithique supérieur d'Europe à travers l'analyse des sépultures primaires : L'exemple de la culture gravettienne, In: Dr. F. Gusi, D. C. Olaria, L. S. Muriel. (eds), La muerte en la infancia, Servicio de Investigaciones Arqueologicas y Prehistoricas de la Diputacion de Castellon y el Laboratorio de Arqueologia Prehistorica de la Universidad « Jaume 1 » de Castellon, p. 331-364.

KARLIN C., PLOUX S., BODU P., PIGEOT N. 1993 - Some socio-economic aspects of the knapping process among groups of hunter-gatherers in the Paris Basin area. Colloque international, Versailles, 25-29 November 1988, Fondation Fyssen Symposium. L'usage de l'outil chez les 
primates humains et non-humains, Berthelet A. et Chavaillon J. (Ed.) Clarendon Press, Oxford, p. 318-337.

KAWALEK E. 2008 - L'atelier de taille de Tercis, Landes : tentative d'attribution chronoculturelle au sein de la séquence aurignacienne et réflexion sur le concept d'apprentissage, Mémoire de Master $1^{\mathrm{re}}$ année, Université de Toulouse II - Le Mirail, 125 p.

KLARIC L. 2006 - Comment interpréter la variabilité technique et qualitative des débitages lamellaires : les nucléus débités par méthode du Raysse à La Picardie (Indre-et-Loire, France), un « cas d'école » du Gravettien moyen d'Europe occidentale », In Aubry T., Almeida F., Araujo A. C., Tiffagom M. dir., Typologie vs Technologie, Résumés de la session $\mathrm{C} 65, \mathrm{XV}^{e}$ congrès de l'UISPP, Lisbonne, 4-9 sept. 2006, p. 391.

KLARIC L. en préparation - New evidence of flint knapping apprenticeship for the Middle Stage of European Western Upper Palaeolithic: the case of Bladelets production at la Picardie (France).

KOZLOWSKI J. K., LENOIR M. 1988 - Analyse des pointes à dos des gisements périgordiens de l'Aquitaine, Uniwersytet Jagiellonski, Cracovie, $94 \mathrm{p}$.

KRALIK M., NOVOTNY V. 2005 - Dermatoglyphics on the ancient ceramics. In : Svoboda J.A. (ed.), Pavlov I Southeast. The Dolni Vestonice Studies, 14, p. 449-477.

LACARRIÈRE J., GOUTAS N., NORMAND C., SIMONET A. avec la collaboration de SCHWAB C. 2011 Vers une redéfinition des occupations gravettiennes de la grotte d'Isturitz (PyrénéesAtlantiques) : révision critique des collections « anciennes » par l'approche intégrée des données lithiques, fauniques et d'industrie osseuse, in Pesesse D. , Goutas N. , Klaric L., Guillermin P. dir., À la recherche des identités gravettiennes : actualités, questionnements et perspectives, Actes de la table ronde d'Aix-en-Provence, 2008, Société préhistorique française (« Mémoire » 52), p. 67-83.

MERLET J.C. 1996 - Le Périgordien supérieur et l'Azilien d'Arcet à Montaut. Archéologie des Pyrénées Occidentales et des Landes, tome 15, p. 119-126.

NORMAND C. 1987 - Le gisement paléolithique de plein air du Vignès à Tercis (Landes), Bulletin de la Société d'Anthropologie du Sud-Ouest, tome XXII, n² 2, p. 71-80.

NORMAND C. 1993 - Un atelier de taille de pièces à dos à Tercis (Landes), Archéologie des Pyrénées occidentales et des Landes, 1992/1993, tome 12, p. 27-51, 6 fig.

NORMAND C. 2002 - Les ressources en matières premières siliceuses dans la basse vallée de l'Adour et de ses affluents. Quelques données sur leur utilisation au paléolithique supérieur. In $\mathrm{N}$. Cazals dir., Comportements techniques et économiques des sociétés du Paléolithique supérieur dans le contexte pyrénéen. Projet collectif de recherche, p. 26-47.

PELEGRIN J. 1995 - Technologie lithique : le Châtelperronien de Roc-de-Combe (Lot) et de La Côte (Dordogne). Cahiers du Quaternaire, $n^{\circ}$ 20, C.N.R.S., 297 p.

PELEGRIN J. 2000 - Les techniques de débitage laminaire au Tardiglaciaire : critère de diagnose et quelques réflexions, In : Valentin B., Bodu P. et Christensen M. (dir.) L'Europe centrale et septentrionale au Tardiglaciaire, Actes de la Table ronde internationale de Nemours, 13-16 mai 1997. Mémoires du Musée de Préhistoire d’Ile de France, 7, éd. A.P.R.A.I.F., Nemours, p. 73-86.

PIGEOT N. 1986 - Apprendre à débiter des lames : un cas d'éducation technique chez les Magdaléniens d'Etiolles, Bulletin de la Société Préhistorique Française, tome 83, p. 67-69.

PIGEOT N. 1988 - Apprendre à débiter des lames : un cas d'éducation technique chez des magdaléniens d'Étiolles, In : J. tixier (ed.), Technologie préhistorique. Paris, éditions du C.N.R.S., p. 63-70. (notes et monographies techniques du cra $\mathrm{n}^{\circ} 25$ ). 
PIGEOT N. 1990 - Technical and Social actors in Prehistory: Flintknapping specialists and apprentices at Magdalenian Etiolles. Archaeological Review from Cambridge, 9, 1, $\mathrm{n}^{\circ}$ special, technology in the Humanities, p. 126-141.

PIGEOT N. dir. 2004 - Les derniers Magdaléniens d'Étiolles, Perspectives culturelles et paléohistoriques (l'unité d'habitation Q31). XXXVIIème supplément à Gallia Préhistoire, CNRS Editions, $351 \mathrm{p}$.

PLOUX S. 1989 - Approche archéologique de la variabilité des comportements techniques individuels : les tailleurs de l'unité 27-M89 de Pincevent, Thèse de Doctorat, Université de Paris X, 2 vol. , 584 p.

PLOUX S. 1991 - Technologie, technicité, techniciens : méthode de détermination d'auteurs et comportements techniques individuels, In 25 ans d'études technologiques en Préhistoire: bilan et perspectives. Actes des XIèmes rencontres internationales d'Archéologie et d'Histoire d'Antibes, 18-20 oct. 1990. Juan-les-Pins : APDCA, 1991, p. 201-214.

POTTIER R. 1872 - Etude préhistorique sur les environs de Dax (Landes), Matériaux pour l'histoire primitive et naturelle de l'Homme, volume 7, série ${ }^{\circ}$ 2, p. 236-243.

REDONDO M. 2011 - L'atelier de taille de l'Avenue du Prissé, Bayonne (64). Approche techno-économique d'un site spécialisé gravettien dans le contexte pyrénéen, Mémoire de Master I, Université de Toulouse II - Le Mirail, 168 p.

SIMONET A. 2004 - L'atelier de taille gravettien de Tercis (Landes). Approche technologique, économique et sociologique : Étude de l'industrie lithique de deux concentrations dites « à pièces à dos » et « à grandes lames ", Mémoire de Maîtrise, Université de Toulouse II - Le Mirail, 203 p., 93 planches et 14 photographies.

SIMONET A. 2008 - L'atelier de taille gravettien de Tercis (Landes) : un cas probable d'apprentissage de la confection d'armatures lithiques, In Pétillon J.-M., Dias-Meirinho M.-H., Cattelain P., Honegger M., Normand C., Valdeyron N. dir., Recherches sur les armatures de projectiles du Paléolithique supérieur au Néolithique, Actes du colloque $\mathrm{C} 83, \mathrm{XV}^{\mathrm{e}}$ congrès de l'UISPP, Lisbonne, 2006), P@lethnologie, 1, p.184-211.

SIMONET A. 2009 - Les gravettiens des Pyrénées. Des armes aux sociétés, Thèse de doctorat, Université de Toulouse II - Le Mirail, 391 p.

SIMONET A. 2010 - Typologie des armatures lithiques gravettiennes de la grotte d'Isturitz (Pyrénées-Atlantiques, France), Oxford, Archaeopress (« BAR International Series » 2156), 133 p.

SIMONET A. 2011 - Le Gravettien du Chantier I de Brassempouy (Landes, France), in Pesesse D. , Goutas N. , Klaric L., Guillermin P. dir., À la recherche des identités gravettiennes : actualités, questionnements et perspectives, Actes de la table ronde d'Aix-en-Provence, 2008, Société préhistorique française (« Mémoire » 52), p. 57-66.

SIMONET A. 2012 - Brassempouy (Landes, France) ou la matrice gravettienne de l'Europe, Liège, ERAUL $133,141 \mathrm{p}$.

TEXIER J. P. 1993 - Géologie du site archéologique de Tercis, Archéologie des Pyrénées occidentales et des Landes, 1992/1993, tome 12, p. 53-59.

THIBAULT C. 1970 - Recherches sur les terrains quaternaires du Bassin de l'Adour, Thèse de Doctorat, Université de Bordeaux I, 4 vol. , 840 p., 171 fig. et LXVIII pl. 


\section{ABSTRACTS}

1. Presentation of the site. The archaeological site of Tercis (Landes, France) has yielded several concentrations of lithic artefacts discovered since the $19^{\text {th }}$ century (fig. 1). The majority of these substantial series were collected by C. Normand from the end of the 1970s onwards during the open cast mining of a large limestone quarry by the "Société des Ciments de l'Adour" (fig. 2). The spatial delimitation of these small concentrations scattered along Tercis ridge over a length of about one kilometer evokes rapid flint knapping activities, carried out in a few hours, providing evidence of short-lived installations linked to the presence of abundant flint on the anticlinal. Many human groups were thus attracted by this raw material since the early stages of the Palaeolithic. But the site was exploited on a larger scale during the Upper Palaeolithic, namely by Gravettians to whom most of the lithic industries can be attributed and notably the small assemblage presented in this paper.

2. Presentation of the assemblage with backed points. This lithic assemblage comes from a concentration which, unfortunately, was not entirely collected because of the short time allotted for rescue excavations by the Société des Ciments de l'Adour (fig. 3 and tab. 1). Tools make up a minority of the assemblage compared to flint knapping products, which is a logical consequence of the workshop context. Among tools, lithic projectile elements are largely dominant (fig. 4 to 6). The original aspects of this assemblage are a poorly executed flint reduction sequence associated with around thirty small backed pieces that are either unfinished and/or failed. These 34 unfinished and/or failed backed pieces are associated with seven cores (fig. 7 to 14), only one of which was productive (fig. 7). This core is also the only specimen which was not made in the grey-black Tercis flint used for other cores and all of the backed pieces. Moreover, a hundred relatively regular laminar blanks attest straight and regular blade production, with standardized dimensions around 2.5 inches long, 0.5 to 0.8 inches wide and 0.2 inches thick (fig. 16 to 19 and tab. 2). This production is also attested by the refitting of several flakes and laminar blanks which yield a reverse image of knappers' intentions (fig. 15).

3. An example of projectile weapon elements apprenticeship? Within the framework of this article, we wish to introduce a palaeo-sociological reflexion based on the accurate presentation of the data. Indeed, this lithic assemblage displays several paradoxes. Firstly, knappers used poor quality flint in a knapping workshop context which is paradoxically suitable for fine production. Secondly, two types of flint exploitation can be observed: on one hand, an exploitation of good quality blocks of raw material which supplied good blanks, such as cores 1, 8 and 9, as shown by the considerable proportion of laminar blanks (fig. 7, 15 and 16). On the other hand, the majority of refitted cores and products testify to the complementary existence of the local exploitation of low quality blocks or flakes (fig. 8 to 14). Finally, straight and regular laminar blanks are not used for backed pieces. What would have motivated knappers to use low quality flint and to select the less regular blades and bladelets to make their backed pieces? The evidence provided by this assemblage point towards the appealing hypothesis of apprenticeship (fig. 20) which has been poorly documented archaeologically up until now (Pigeot 1988; Ploux 1991; Pelegrin 1995; Klaric 2006, in preparation). Although we cannot definitively advocate this latter hypothesis, we nevertheless propose to assess the archaeological facts, which are, as of yet, restricted, in order to propose a relevant methodology for the restitution of gestures and intentions.

\section{INDEX}

Keywords: Tercis, knapping workshop, Gravettian, projectile weapon element, apprenticeship 
AUTHOR

\section{AURÉLIEN SIMONET}

TRACES - UMR 5608 - Maison de la Recherche, 5, allées A. Machado 31058 Toulouse Cedex 9 simonetaurelien@yahoo.fr 